\title{
„Powinności” nauczyciela ludowego doby zaborów w przekazie czasopisma ,Szkoła”
}

\begin{abstract}
Duties" of a folk teacher in the period of the Partitions of Poland in the message of the "Szkoła" journal

The aim of the article is to analyse the pedeutological texts published in the era of the Partitions of Poland in the pages of the oldest Galician pedagogical periodical, which "Szkoła" was. The journal, edited by teachers and educational activists, addressed mainly to folk school teachers, published uninterruptedly for 70 years, is for today's researchers an invaluable source of knowledge about the functioning of Galician education and its employees. The editors and collaborators of the journal often took up such important subjects as vocation, role models of folk teachers, relations with pupils' family homes or difficult realities of teacher's work. Teachers received a lot of specific advice concerning the upbringing and education of pupils, frequently from older and experienced colleagues. They could also learn a catalogue of traits and attitudes expected from folk teachers, concerning also their own families or taking up additional work.
\end{abstract}

Keywords: Galician teachers, community school, folk teacher, educational magazine "School"

Już w pierwszym roku ukazywania się galicyjskiego pisma „Szkoła” opublikowano artykuł zastępcy dyrektora lwowskiego Gimnazjum im. Franciszka Józefa, Stanisława Sobieskiego ${ }^{1}$, pod wymownym tytułem Czego mamy obecnie żąać po nauczycielu szkół ludowych ${ }^{2}$. Zapoczątkował on na łamach tego najstarszego lwowskiego periodyku

1 W. Szulakiewicz, Stanisław Sobieski-życie i poglądy na wychowanie narodowe, w: Galicja i jej dziedzictwo, t. 9: Biografie pedagogiczne, red. C. Majorek, J. Potoczny, Rzeszów 1997, s. 59-67; Redakcja, Sobieski Stanisław, w: Polski Stownik Biograficzny, t. 39, Warszawa-Kraków 1999-2000, s. 510-511; A. Meissner, Stanisław Sobieski, w: Stownik biograficzny polskiej historii wychowania, red. A. Meissner, W. Szulakiewicz, Toruń 2008, s. 758-762; idem, Historia i historycy wychowania na ziemiach polskich w XX wieku, Lublin 2010, s. 266-268.

2 S. Sobieski, Czego mamy obecnie żądać po nauczycielu szkót ludowych, „Szkoła” 1868, t. 1, nr 4. 
pedagogicznego dyskusję o ideale i realiach codziennej pracy zawodowej nauczyciela ${ }^{3}$. W kolejnych numerach pisma, już z 1869 r., rozważano m.in. różnorakie uwarunkowania skuteczności jego pracy oraz możliwości wpływu na podniesienie ogólnego poziomu wykształcenia warstw ludowych ${ }^{4}$.

Młodzi pedagodzy czytający to pismo otrzymywali liczne i konkretne wskazówki dotyczące metod zdobywania przychylności uczniów i rodziców, konieczności aktywnego uczestnictwa w życiu lokalnej społeczności, poznania środowiska, w którym pracowali oraz nieodzownych w ich zawodzie informacji dotyczących taktu i pokory. $\mathrm{Na}$ kartach „Szkoły” mogli też zapoznać się z refleksjami starszych kolegów na temat zderzenia wyobrażeń początkującego adepta tego zawodu z rzeczywistością. Znalazły się wśród nich porady dotyczące m.in. unikania zarozumiałości (która miała cechować zwłaszcza młodych nauczycieli), czerpania z doświadczeń bardziej doświadczonych pedagogów oraz poświęcenia większości czasu na sprawy szkoły i wychowanków. Przedstawienie głównych kierunków dyskusji dotyczących pracy i ideałów nauczycieli szkół ludowych Galicji publikowanych na łamach „Szkoły” w dobie zaborów ma na celu uzupełnienie badań z zakresu pedeutologii historycznej.

\section{Powołanie i ideały a trudne warunki pracy nauczycieli}

Ideaty to bańka mydlana! - wota dusza, sobkostwem zaśniedziała - $i$ nie posiada ich wcale; ale to wlaśnie ideaty, to jak wydęte pęcherze, które wśród batwanów życia i świata utrzymuja nas na powierzchni i chroniq od utonięcias.

Na łamach „Szkoły” pojawiały się apele, by dobrze rozważyć decyzję o wyborze zawodu nauczyciela i ocenić, czy ma się do niego powołanie:

\footnotetext{
${ }^{3}$ Szerzej na temat czasopisma w m.in. „Szkoła” 1892, nr 1 (numer jubileuszowy); Sprawozdanie Bolestawa Adama Baranowskiego odczytane na posiedzeniu Zjazdu Towarzystwa Pedagogicznego dnia 27 sierpnia 1908 r. pt. Czterdziestolecie Towarzystwa Pedagogicznego, w: Ksiega Jubileuszowa Polskiego Towarzystwa Pedagogicznego 1868-1901, Lwów 1908, s. 3-4; A. Karbowiak, Polskie czasopisma pedagogiczne, Warszawa 1912; W. Bobrowska-Nowak, Problemy pedagogiczne na tamach „Szkoly” w latach siedemdziesiatych ubiegłego stulecia, „Przegląd Historyczno-Oświatowy” 1971, nr 2, s. 261-277; C. Majorek, Towarzystwo Pedagogiczne $i$,,Szkoła” wobec projektów reform ksztatcenia nauczycieli ludowych w Galicji z lat 1868-1869, „Rocznik Naukowo-Dydaktyczny WSP w Krakowie" 1972 (z. 43), nr 5, s. 289-300; A. Stopińska-Pająk, Wkład czasopisma ,Szkoła” w rozwój myśli pedagogicznej, w: Galicja i jej dziedzictwo, t. 8, Myśl edukacyjna w Galicji 1772-1918, red. C, Majorek, A. Meissner, Rzeszów 1997, s. 169-179; A. Wałęga, Galicyjska „Szkoła” jako przykład czasopisma pedagogicznego okresu zaborów, „Acta Universitatis Nicolai Copernici - Pedagogika", t. 29 (2013), s. 9-28.

${ }^{4}$ Z. Sawczyński, Na czym zależy przede wszystkim skuteczne działanie nauczyciela w szkole niższej czyli tak zwanej ludowej, „Szkoła” 1869, nr 1, s. 1-5, nr 2, s. 17-23; F. Nowakowski, Nauczycieli byt dobry a praca sumienna i umiejętna nieodzownym warunkiem oświaty ludu (rzecz czytana na zgromadzeniu oddziału wadowickiego Towarzystwa Pedagogicznego), „Szkoła” 1869, nr 29, s. 33-41.
}

${ }^{5}$ S. Gonet, Działalność nauczyciela poza szkoła, „Szkoła” 1899, nr 26, s. 255. 
Znaczy to poznać obowiązki pewnego zawodu, a następnie zbadać usposobienie własne i wyrozumieć, czy pomiędzy obowiązkami swymi a skłonnościami duszy naszej panuje zgoda, kto czuje w sobie uzdolnienie do zdobywania wiedzy oraz przymioty niezbędne $\mathrm{w}$ zawodzie nauczycielskim, ten posiada powołanie. Nie należy tylko mieszać powołania z jakiemś chwilowym pragnieniem czy zachceniem".

Podkreślano przede wszystkim rangę zawodu oraz jego istotne znaczenie w życiu społecznym. Główne zadanie nauczycieli to upowszechnienie oświaty wśród jak najszerszych grup społeczeństwa oraz kształtowanie w ten sposób większych możliwości edukacyjnych i zawodowych przyszłych pokoleń7. Aby kandydaci do tego zawodu mogli zrealizować to ważne zadanie, powinno cechować ich „szczere zamiłowanie nauki” oraz świadomość, że rola pedagoga ludowego jest nie tylko najtrudniejsza, ale i najważniejsza. Pojawiały się nawet sugestie, że pod względem zakresu obowiązków i odpowiedzialności w stosunku do społeczeństwa przewyższa rolę profesorów wyższych uczelni ${ }^{8}$. Przypominano: „Zamiłowanie zawodu, przejęcie się wysokim tegoż zadaniem [...], oto są przymioty, które zdobić powinny każdego nauczyciela i którymi każdy nauczyciel powinien młodzieży przyświecać!"’"

Wiele zależało od tego, w jaki sposób człowiek postrzegał ten zawód, czy traktował go jako rzemiosło, czy jako sztukę ${ }^{10}$, czy zależało mu jedynie na zapewnieniu sobie bytu, czy też jego celem było ogólne uszlachetnienie i umoralnienie, „kształcenie i podnoszenie ducha""11. Przestrzegano, by nie podejmować pracy nauczyciela bez powołania, kierując się jedynie „koniecznością losu, aby co rychlej mieć jaki taki kawałek chleba"12. Apelowano też o twórcze uprawianie pedagogiki:

Twórcą być musisz nauczycielu - sztukmistrzem, artystą, jeśli nie pragniesz zejść do rzędu wyrobników codziennych. Zawód nasz powinniśmy pojmować na równi ze sztuką, szlachetną sztuką, która w dziedzinie ducha dokonywa dzieł wysokiej wartości. A przedmiotem naszej sztuki jest człowiek [...] - a dłutem i pędzlem, serca nasze, wiedza, nauka ${ }^{13}$.

Porównywano nawet zawód nauczycielski do kapłaństwa, gdyż w obu tych przypadkach należy poświęcić wiele czasu na właściwą realizację przypisanych im zadań. Ich zakres bowiem wykracza znacznie poza godziny spędzone w szkole, na lekcjach czy na

${ }^{6}$ Z.M., Powołanie nauczyciela elementarnego, „Szkoła” 1908, nr 51, s. 401-402.

7 S. Chlebowski, Nauczyciel, ,Szkoła” 1868, t. 1, nr 1, s. 7.

8 Ibidem, s. 9.

9 M. Baranowski, O zadaniu szkoty ludowej i o środkach za pomoca których zadanie to można osiagnąć, „Szkoła” 1890, nr 27, s. 337.

10 J. Chmielowski pisał, że „narzekają zwykle młodzi nauczyciele a przecież praca nie jest monotonna jak praca rzemieślnika”. Por.: idem, O zamiłowaniu w zawodzie, „Szkoła” 1880, nr 9, s. 67-69.

11 B. Marczewski, Powołanie, godność i obowiązki stanu nauczycielskiego, „Szkoła” 1891, nr 1, s. 3-4, nr 2, s. 15-16, nr 3, s. 27-29.

12 S. Zabierzowski, O koleżeństwie, „Szkoła” 1889, nr 35, s. 337.

13 B. Marczewski, ibidem, nr 3, s. 29. 
celebracji nabożeństw w kościołach ${ }^{14}$. Aby właściwie spełnić powołanie nauczycielskie należy najsumienniej i z zaangażowaniem realizować wszystkie obowiązki zawodowe: „Jakże wielce pożałowania godni ci, którzy obowiązki swe jak rzemieślnicy partacze, lekceważąco z dnia na dzień spychają. Ci nieszczęśliwi, oprócz goryczy wynikającej z zawodu, truć się muszą goryczą własnego sumienia"15.

Wielokrotnie w tekstach kierowanych do nauczycieli współpracownicy i redaktorzy „Szkoły” przytaczali zalecenia Grzegorza Piramowicza i przepisy Komisji Edukacji Narodowej ${ }^{16}$. Czasem wskazywano pracownikom szkół ludowych konkretne wzory do naśladowania, przede wszystkim pedagogów, którzy szczególną troską otaczali rozwój tego szczebla szkolnictwa ${ }^{17}$. Oprócz przywoływanego wielokrotnie Jana Henryka Pestalozziego, takimi postaciami byli Jan Amos Komeński, Adolf Diesterweg, Fryderyk Froebel, Karl Kehr, Lorenz Kellner i August Jeske. Wśród rodaków, oprócz wspominanego najczęściej Grzegorza Piramowicza, byli to Ewaryst Estkowski ${ }^{18}$, Andrzej Józefczyk ${ }^{19}$ czy Zygmunt Sawczyński ${ }^{20}$.

Nawet związane z wykonywaniem tego zawodu liczne problemy nie powinny zniechęcać nauczycieli do pracy. Podejmowano tu m.in. wątek przeciążenia, w kontekście poprawiania prac domowych uczniów i prowadzenia dokumentacji ${ }^{21}$, czy nauczania zbyt

${ }^{14}$ S. Pallan, Obowiązki nauczyciela. Parafraza \$32 Tyt. V Regulaminu dla szkół ludowych, „Szkoła” 1888, nr 4, s. 25 .

15 Ibidem.

${ }_{16}$ Por. m.in. S. Spitzer, W jaki sposób wpływać może szkoła na wzbudzenie u dzieci poczucia obowiązku, „Szkoła” 1899, nr 21, s. 202-204, nr 22, s. 211-212, nr 24, s. 233-235, nr 27, s. 263-265.

17 J. Chmielewski, O idealiźmie w życiu nauczycielskim, „Szkoła” 1888, nr 1, s. 3-5.

${ }^{18} \mathrm{Na}$ ten temat szerzej A. Wałęga, Dziedzictwo wielkopolskiej myśli pedagogicznej w przekazie „,Szkoły” (1868-1939), w: Wielkopolska i Wielkopolanie w dziejach polskiej edukacji, red. E. Głowacka-Sobiech, K. Kabacińska-Łuczak, Wydawnictwo Naukowe Uniwersytetu im. Adama Mickiewicza, Poznań 2017, s. 475-489.

${ }^{19}$ Andrzej Józefczyk (1816-1878) - organizator i pierwszy dyrektor seminarium nauczycielskiego męskiego w Krakowie, stały współpracownik „Szkoły”, autor podręczników szkolnych. Jako młody człowiek był aktywnym uczestnikiem ruchu konspiracyjnego w Galicji - przez swojej zaangażowanie trafił do więzienia i nie ukończył studiów, pracował jako nauczyciel domowy i na prywatnych pensjach. Szerzej na ten temat: K. Lewicki, Józefczyk Andrzej, w: Polski Słownik Biograficzny, t. 11, Wrocław 1964-1965, s. 303; A. Meissner, Spór o duszę polskiego nauczyciela. Spoleczeństwo galicyjskie wobec problemów kształcenia nauczycieli, Rzeszów 1999, s. 96-97.

${ }^{20}$ Zygmunt Sawczyński (1826-1893) - absolwent Uniwersytetu we Lwowie, nauczyciel szkół średnich Tarnowa, Krakowa, Czerniowic i Sambora. Po serii nieprzyjemności ze strony władz austriackich porzucił karierę nauczycielską. Podjął pracę literacką i dziennikarską, a po 1867 r. zaangażował się w działalność Wydziału Krajowego, Rady Państwa, Rady Szkolnej Krajowej. Współorganizował i kierował pierwszymi seminariami nauczycielskimi we Lwowie, pracował czynnie w komisjach egzaminacyjnych dla nauczycieli. Od 1873 przez szereg kadencji piastował funkcję prezesa Towarzystwa Pedagogicznego, łącznie 20 lat. Szerzej na ten temat min.: E. Głaz, Zygmunt Sawczyński - pedagog, polityk i działacz oświatowy, w: Galicja i jej dziedzictwo, t. 9, Biografie pedagogiczne. Szkice do portretu galicyjskiej pedagogii, red. C. Majorek, J. Potoczny, Rzeszów 1997, s. 41-58.

${ }^{21}$ St. K., Przeciążenie ale nauczycieli, „Szkoła” 1902, nr 40, s. 297-298; St. Szyc, Jeszcze o przeciążeniu, „Szkoła” 1902, nr 41, s. 332-333. 
dużej liczby uczniów (np. jeden nauczyciel na 220 osób). Wspominano też o niechęci do obejmowania posad na prowincji w związku z panującymi tam trudnymi warunkami bytowymi ${ }^{22}$.

Najczęściej podejmowano jednak wątki ekonomiczne. U schyłku XIX w., podczas jednej z debat sejmowych sformułowano znamienny apel, by nauczyciele zadowolili się dotychczasowymi zdobyczami socjalnymi i pamiętali o tym, że ich zawód jest jednocześnie „szczytny i przykry”. To stwierdzenie stało się podstawą artykułu zamieszczonego na łamach „Szkoły” zatytułowanego wymownie Czy zawód nauczyciela ludowego jest szczytnym i czy przykrym musi być koniecznie ${ }^{23}$. Do przykrych stron tego zawodu przypisano negatywny stosunek części społeczeństwa wobec postulatów wyższego niż dotychczas wykształcenia nauczycieli ludowych, zaostrzenia selekcji kandydatów oraz poprawy ich sytuacji materialnej. W tej sytuacji wielu spośród przyszłych nauczycieli dyskusja o szczytności tego zawodu wydawała się niepoważna i podszyta ironią, gdyż realia pracy znacząco odbiegały od „szczytnych” haseł. Anonimowy autor przytaczanego tekstu stwierdził jednak, że zawód ten nie musi być koniecznie przykrym, należy pamiętać bowiem o tym, że pracuje się i wychowuje dla dobra innych, a wychowanie to jednocześnie sztuka i umiejętność, co daje pedagogom wiele możliwości rozwoju osobistego. Zarobki nie są wysokie, lecz większość nauczycieli potrafi żyć skromnie, chodzi jednak o to, by nie musieli oni żyć w niedostatku².

Wielokrotnie na łamach pisma popierano postulaty zwiększenia płac nauczycielskich, nie zawsze jednak zgadzano się z ich uzasadnieniami. Niektórzy argumentowali, że wyższe wynagrodzenie zapewni powagę i szacunek w oczach społeczeństwa. Zdaniem jednego $\mathrm{z}$ anonimowych uczestników tej dyskusji owa powaga i szacunek nie zależą bynajmniej od stanu posiadania. Co prawda, uznaje on argumenty, że lepiej nosić modny surdut, jedwabny kapelusz i stołować się w ekskluzywnym lwowskim hotelu Żorż, jednak dla wielu ważniejsze jest, co taki człowiek nosi pod owym kapeluszem, a zatem co sobą prezentuje. Apelował, by nauczyciele nie zwracali uwagi na zewnętrzne pozory blichtru i nie domagali się przyznania im pewnych praw jako rzeczy oczywistej. Powinni uczciwie i solidnie pracować, dawać dobry przykład - wówczas bez żadnych starań zostaną zaproszeni do członkostwa w gremiach, na których im zależy (takich jak rada gminy czy Sejm Krajowy ${ }^{25}$.

Niektórzy ze współpracowników „Szkoły” zdawali sobie jednak sprawę z tego, że nauczyciele ludowi, spędzający czas wśród niewykształconego ludu, rzadziej obcujący z innymi wykształconymi osobami, często wyśmiewani, uwikłani w różnorakie zależności służbowe, obarczeni licznymi obowiązkami i codzienną walką o byt, którą utrudnia niska

22 Z nauczycielskiej martyrologii, „Szkoła” 1902, nr 46, s. 348.

${ }^{23}$ B.O., Czy zawód nauczyciela ludowego jest szczytnym i czy przykrym musi być koniecznie?, „Szkoła” 1896, nr 13, s. 115.

${ }^{24}$ Ibidem, s. 114-116.

${ }_{25}$ Jak zdobyć powage i szacunek dla stanu nauczycielskiego?, „Szkoła” 1897, nr 43, s. 475. 
płaca, negatywnie reagują na zalecenia dotyczące znaczenia idealizmu w tym zawodzie. Jak pisał Józef Chmielewski, sam będący synem nauczyciela i kontynuujący tradycję rodzinną: „Czyż w takim razie poczytamy mu za złe, gdy zniechęcony i cierpko nastrojony zawoła niekiedy: Ideały to mydlane bańki!"26. Zalecał, by często porównywać ideały z rzeczywistymi realiami, nie tracąc jednak z oczu przykładów wytrwałej pracy tych, którzy nie ulegli w obliczu licznych przeszkód. Jako wzory do naśladowania podaje, jak inni, przykład Estkowskiego, poszerza jednak to grono także o Hipolita Seredyńskiego ${ }^{27}$.

Warto podkreślić, że już w 1868 r. Stanisław Sobieski apelował, by nie tracić ideałów:

wielu może nam zarzucić, iż żądamy po nauczycielu czegoś nadzwyczajnego, iż kreślimy ideały. Na to odpowiadamy: tylko ludzie czołgający się po ziemi, nie cierpią ideałów swego zawodu i śmieją się z nich. Jeżeli istotnie ideały streściłem, to dążmy do nich, wszak całe życie dzielnego człowieka jest dążeniem do doskonałości, do ideałów ${ }^{28}$.

Natomiast w 1900 r. redakcja „Szkoły” zamieściła na łamach pisma wiersz pt. Zwyciężę! Marzenia w chwili wyboru zawodu polskiego nauczyciela-wychowawcy ${ }^{29}$.

\section{Katalog pożądanych cech i postaw nauczycieli}

[...] miłość do dziatwy, tagodność i cierpliwość w obejściu, zdolność panowania nad soba, uprzejmość połaczona ze statecznościa i powaga, bezstronność, religijność, miłość ojczyzny, poszanowanie ustaw, władz i przełożonych, oto sa przymioty, które zdobić powinny każdego nauczyciela ${ }^{30}$.

Od nauczycieli wymagano cnót moralnych, które mogły być wzorem dla ludu, gruntownego przygotowania merytorycznego oraz ogólnych uzdolnień pedagogicznych ${ }^{31}$.

${ }^{26}$ J. Chmielowski, O idealiźmie $w$ życiu nauczycielskim, „Szkoła” 1888, nr 2, s. 10. Tekst ten to odczyt wygłoszony przez autora w Andrychowie podczas spotkania nauczycieli, oparty na artykule niemieckiego nauczyciela z Alzacji, niejakiego Heylera.

${ }^{27}$ Hipolit Seredyński (1800-1874) - nauczyciel, działacz społeczny, członek Towarzystwa Naukowego Krakowskiego, członek Rady Szkolnej Krajowej, inspektor szkół krakowskich, autor prac pedagogicznych. Często spotykały go szykany władz politycznych i oświatowych, jednak nie powstrzymywało go to przed kontynuowaniem prac na polu edukacji. Ojciec znanego galicyjskiego pedagoga Władysława Seredyńskiego. „Szkoła” w 1874 r. poświęciła mu obszerną notkę: R., Hipolit Seredyński. Wspomnienie pośmiertne, „Szkoła” 1874, nr 23, s. 197-198, nr 24, s. 206-207, nr 25, s. 218-219. Na ten temat szerzej: W. Szulakiewicz, Władysław Seredyński. Studium z dziejów pedagogiki galicyjskiej, Rzeszów 1995, s. 25-27.

28 S. Sobieski, Czego mamy obecnie żądać po nauczycielu szkół ludowych, „Szkoła” 1868, t. 1, nr 4, s. 237.

29 „Szkoła” 1900, nr 27, s. 214-215. Autorem wiersza był Julian Nowakowski.

${ }^{30}$ M. Baranowski, O zadaniu szkoty ludowej i o środkach za pomoca których zadanie to można osiagnąć, „Szkoła” 1890, nr 27, s. 337.

${ }^{31}$ Reforma szkót i Seminaria Nauczycielskie, „Szkoła” 1870, nr 41, s. 644. 
Wśród tych ostatnich akcentowano szczególnie umiejętności skutecznego przekazywania wiedzy oraz nawiązywania kontaktu z uczniami ${ }^{32}$. Zalecano nawet troskę o pielęgnowanie i zachowanie w sobie samym dziecka. Podawano konkretne wskazówki służące pozyskaniu sympatii wychowanków. Zalecano punktualność i pilność, unikanie złego nastroju w pracy, uśmiechanie się do dzieci, a nawet rozweselanie ich przyzwoitymi żartami. Ważne było indywidualne podejście do poszczególnych uczniów, poznawanie ich. Klucz do sukcesu stanowiła jednak umiejętność zainteresowania dzieci i utrzymania ich uwagi:

Nauczyciel, który [...] umie uczyć zajmująco, umie dzieciom pokazywać obrazki, zręczne o nich prowadzić rozmowy, w czasie wypoczynku lub pauzy zaśpiewać stosowne piosenki, wykonać zgrabne ruchy, powiedzieć zagadkę, powiastkę, anegdotę lub w ogóle coś ciekawego [...], zdobędzie sobie przywiązanie, stanie się ulubieńcem dzieci. Będą lgnęły do niego, chętnie przychodziły do szkoły i to pewnie chętniej, niż za pomocą przymusu szkolnego ${ }^{33}$.

Jako najważniejszy element w wychowaniu i zachowaniu autorytetu wskazywano osobisty przykład nauczyciela. Podkreślano, że „każdy uczeń nosi w sobie cząstkę nauczyciela; po tej osądzą nas współcześni i potomni”34. Dlatego pedagog, zwłaszcza na wsi, nieustannie powinien uważać na swoje zachowanie. Jako „kardynalne przymioty nauczyciela" wymieniano religijność, moralność, sprawiedliwość (co wymagało dobrej woli, inteligencji oraz ciągłej analizy zachowania uczniów i ich reakcji na kary) oraz miłość do dzieci ${ }^{35}$, Boga, narodu i ojczyzny. Ta ostatnia miała szczególne znaczenie w obliczu panującej w Galicji ideologii wychowania narodowego i wyznaczania nauczycielowi roli „stróża uczuć narodowych”36. Taki pedagog, doskonale przygotowany merytorycznie, powinien też szczególnie dbać o poprawne stosowanie w szkole i poza nią języka polskiego oraz legitymować się roztropnością, ogładą towarzyską, taktem pedagogicznym oraz swoistą rutyną dydaktyczno-metodyczną ${ }^{37}$. Ta rutyna obejmowała

32 Ibidem, s. 643.

33 J. Chmielewski, Jak może nauczyciel pozyskać miłość i szacunek dzieci, jako też i gminy, „Szkoła” 1880, nr 41, s. 341 .

34 J. Nowakowski, Przykład nauczyciela, „Szkoła” 1885, nr 1, s. 2-3.

35 Tę miłość nauczyciela względem uczniów szerzej charakteryzuje W.M. Bernadzikiewicz: „Nauczyciel dobry powinien dziecko sobie powierzone ukochać jak swoje, być dla niego drugim ojcem i opiekunem: winien on się także i o to starać , aby rodzice dziecku krzywdy nie wyrządzali, jak to się u ludu naszego na wsi często zdarza; a zjedna sobie u dziecka miłość niezachwianą, wywdzięczy mu się ono za to, złoży na jego ręku serce duszę, aby żyła i wzrastała w cieple ożywczym miłości, za którą dziecko ugania, o którą pyta i stara się", W.M. Bernadzikiewicz, O miłości nauczyciela ku uczniom, „Szkoła” 1870, nr 22, s. 347.

${ }^{36}$ E. Petryka, Jakie przymioty powinien posiadać dobry nauczyciel, „Szkoła” 1870, nr 18, s. 278. Na ten temat szerzej E. Gabryelski, O wychowaniu narodowym i o posłannictwie nauczycielstwa ludowego, „Szkoła” 1895, nr 23, s. 297-299, nr 24, s. 310-311, nr 32, s. 417-418, nr 34, s. 438-441; A. Świątek, Problem patriotycznego wychowania ludu na łamach lwowskiej ,,Szkoly” w czasach autonomii galicyjskiej, w: Czasopiśmiennictwo XIX i początków XX wieku jako źródło do historii edukacji, red. I. Michalska, G. Michalski, Wydawnictwo Uniwersytetu Łódzkiego, Łódź 2010, s. 169-184.

37 E. Petryka, op. cit., nr 18, s. 273-278, nr 19, s. 289-293. 
m.in. powagę, umiejętność zaprowadzenia karności oraz stosowanie metod pytań i odpowiedzi. Nauczyciel miał ponadto dobrze znać świat i starać się traktować równo wszystkich wychowanków ${ }^{38}$.

Wychowawca miał być zatem przede wszystkim pogodny, łagodny i cierpliwy, a zatem potrafiący panować nad sobą i swoimi rekcjami, serdeczny, znający ludzkie słabości i wyrozumiały wobec nich przy jednoczesnym zwalczaniu takich objawów u siebie samego. Powinien być on „znawcą ludzi” - czyli posiadać solidne przygotowanie psychologiczne - oraz chrześcijaninem. Inne pożądane cechy to żywość i pogoda umysłu, wyobraźnia, miłość do zawodu i wychowanków oraz doskonała orientacja w naukach przyrodniczych i historii. Zalecano, by był wytrwały w osiąganiu celów zawodowych, pracowity, pełen dobrych chęci, w tym także do samokształcenia ${ }^{39}$.

Charakteryzować go miała ponadto nieposzlakowana opinia, pokora, skromność, bezkonfliktowość, punktualność, konsekwencja i sprawiedliwość ${ }^{40}$. Wśród jego zalet wymieniono także przyjazność, szczerość, otwartość, prawdomówność, delikatność i łagodność. Taki wzorowy nauczyciel dbał o zachowanie samodzielności, unikał wszelkich zależności, które wywoływało m.in. przyjmowanie podarunków od uczniów czy różnego rodzaju przysługi ${ }^{41}$.

Profesjonalny nauczyciel powinien uwzględniać w swoich działaniach naturalną ciekawość dzieci i ich praktyczną naturę, nauczać poglądowo, wdrażać do samodzielności i współzawodnictwa. Musiał pamiętać jednak także o ich subiektywnym pojmowaniu świata, niechęci do nauki i wadach charakteru, takich jak ,upór, zazdrość, uciecha z cudzej szkody lub nieszczęścia, pustota, trzpiotowatość i chamstwo"42. Stanowczy, skromny i taktowny, kary wymierzał zawsze bez emocji, unikał wszelkiej dwuznaczności, zachowując zawsze pogodę ducha i wesołość. Nie wolno mu było ujawniać uczniom własnych problemów czy lekceważyć wychowanków - powinien ich kochać jak własne dzieci, na wzór Pestalozziego, w czym pomóc mu miała grzeczność i familiarność, unikanie trzpiotowatości i niedbałości oraz moralne i uporządkowane życie ${ }^{43}$.

Zwracano uwagę na inteligencję pedagogów oraz ich przygotowanie do pracy dydaktycznej i wychowawczej:

Pod względem zaś wewnętrznym, czyli duchowym, górować winna w nauczycielu dobra pamięć, bystrość, łatwość zastosowania się do każdej, nawet nieprzewidzianej sytuacji i żywa,

${ }^{38}$ F.K. Wojnarski, Jakim powinien być nauczyciel?, „Szkoła” 1874, nr 6, s. 47-48, nr 7, s. 57.

${ }^{39} \mathrm{Na}$ ten temat szerzej m.in. A. Wałęga, Kształcenie $i$ samokształcenie galicyjskich nauczycieli szkół ludowych doby zaborów w przekazie ,,Szkoły”, w: Szkoła polska od XVIII do XXI wieku, red. R. Ślęczka, A. Włoch, J. Wojniak, Kraków 2020, s. 46-65.

40 J. Chmielewski, Jakie sa przymioty dobrego nauczyciela, „Szkoła” 1876, nr 15, s. 137-139; idem, W jaki sposób może się nauczyciel przyczynić do podniesienia szkół w gminie?, „Szkoła” 1880, nr 1, s. 2-4.

41 Ibidem, nr 2, s. 9-11.

42 Idem, Jak może nauczyciel pozyskać miłość, op. cit, s. 340.

${ }_{43}$ Ibidem, nr 40, s. 333-334, nr 41, s. 339-342, nr 42, s. 351-352, nr 43, s. 360-362. 
na wodzy trzymana fantazja wraz ze stanowczością i szybkością w wydawaniu sądów, jako też w układaniu pytań ${ }^{44}$.

Wymagano od niego szerokiego zasobu uporządkowanej wiedzy oraz umiejętności jej dostosowania do poziomu uczniów, energii i zapału połączonego z powagą i głęboką religijnością.

Wielokrotnie przypominano pedagogom, że ,tylko taki nauczyciel jest ideałem młodzieży, w prawdziwym tego słowa znaczeniu, który dzielnością charakteru, siłą woli i surową powagą, nacechowaną pewną dozą dobroci i łagodności przyciąga serca młodzieńcze ku sobie; tylko tam potrafi się zrodzić prawdziwe zaufanie" ${ }^{45}$. Młodzież niezwykle szybko i trafnie odczytuje słabości swoich nauczycieli, potrafi je wykorzystać do własnych celów i w ten sposób obniża powagę wychowawców. Dlatego nie wolno być pobłażliwym, szukać poklasku, przechwalać się swoją wiedzą czy sukcesami wychowawczymi. Wymieniano podstawowe zalety nauczyciela: nieugiętość i konsekwencja połączone z wyrozumiałością ojcowską, sprawiedliwością, bezstronnością, taktem, obowiązkowość i zaangażowanie.

Nauczycielowi nie wolno było być rubasznym, gwałtownym, nieobyczajnym, skłonnym do karania uczniów w gniewie, ujawniającym swoje wady charakteru oraz nieprzygotowanym merytorycznie do nauczania. Uczulano nauczycieli, że brak wiedzy podważa zaufanie uczniów ${ }^{46}$.

Nauczyciele byli zobowiązani do regularnej autorefleksji. By ułatwić im ten ważny element samooceny swoich kwalifikacji oraz efektów pracy zawodowej, na kartach „Szkoły” podawano konkretne wykazy pytań, które każdy reprezentant tego zawodu powinien sobie często zadawać. Dotyczyły one następujących kwestii: dalszego kształcenia i samokształcenia, troski i konkretnych zabiegów o rozwój szkoły, wychowania dzieci, umiejętności utrzymywania dyscypliny, kontroli nad zachowaniem się uczniów poza szkołą, przestrzegania planów nauczania, przygotowania merytorycznego i metodycznego nauczyciela do każdej lekcji ${ }^{47}$, metod, form i wyników procesu nauczania oraz wnikliwości i częstotliwości sprawdzania pisemnych prac uczniów ${ }^{48}$. Autorefleksja dotyczyła także respektowania przepisów prawa oświatowego, czyli przestrzegania regulaminu zawodowego, wykonywania poleceń przełożonych i władz oświatowych ${ }^{49}$.

Od nauczycieli szkół ludowych oczekiwano także wdrożenia uczniów do samokształcenia, tak by po ukończeniu nauki nie zaprzestali oni procesu kształcenia.

${ }^{44}$ J. Dobrowolski, Kilka słów o indywidualności nauczyciela, „Szkoła” 1889, nr 9, s. 83-84.

${ }^{45}$ I. Nowicki, Zaufanie uczniów do nauczyciela, „Szkoła” 1898, nr 8, s. 70.

46 J. Chmielewski, O zaufaniu dzieci do nauczyciela (podlug Salkmanna), „Szkoła” 1879, nr 1, s. 2-3.

${ }^{47}$ Zalecano, by analizować każdą zrealizowaną lekcję pod kątem ewentualnych błędów. Por.: S. Pallan, op. cit., s. 36 .

${ }^{48}$ F.K. Wojnarowski, Dlaczego i jak powinien nauczyciel doświadczać samego siebie, „Szkoła” 1872, nr 48 , s. $377-380$.

${ }^{49}$ S. Pallan, op. cit., s. 36. 
Uznawano, że będzie to możliwe tylko wówczas, gdy okres nauki szkolnej pozostawi w wychowankach dobre wspomnienia. Dlatego pedagodzy mieli unikać przemęczania dzieci nauką i zadaniami domowymi, monotonii, źle pojmowanej karności, niesprawiedliwości, zgryźliwości, krytycyzmu czy stronniczości. Zalecano metody aktywizujące, wycieczki, naukę poglądową, dobór ciekawych lektur i przykładów interesujących dla dzieci ${ }^{50}$.

Jako jedno z ważnych zadań nauczyciela wymieniano przyzwyczajanie uczniów do samodzielnej lektury, miał on zainteresować młodzież czytaniem, opowiadając barwnie treść wybranej lektury. W szkole zalecano oswajać z tą formą samorozwoju tak, by następnie stała się ona nawykiem każdego dziecka. Należało przestrzegać zasady „efektywnego czytania”, czyli takiego, które poszerza horyzonty. W tym celu uczniowie referowali zwięźle treści przeczytanych dzieł, a nauczyciel dbał o syntezę nabytych w ten sposób treści z programem szkolnym, zwłaszcza w zakresie języka ojczystego, geografii czy historii. Pedagodzy powinni uważać, by nie przeciążyć podopiecznych lekturami oraz zachęcać ich do głośnego czytania pozostałym członkom rodziny, zwłaszcza w niedzielę. Jednocześnie ważnym zadaniem wychowawców było kształtowanie szacunku do książek, zaszczepienie potrzeby ich kupowania oraz kontrola nad doborem właściwych lektur i ostrzeżenia przed zgubnym wpływem niektórych dzieł ${ }^{51}$.

Wymieniano też najczęściej popełniane przez nauczycieli zaniedbania. Dotyczyły one przede wszystkim bagatelizowania samokształcenia, lekceważącego stosunku do ludu, niesumiennego wykonywania obowiązków zawodowych oraz niewłaściwego postępowania i „prowadzenia się”. Powołując się na wytyczne Komisji Edukacji Narodowej i Grzegorza Piramowicza ${ }^{52}$, pisano o godności nauczycieli, o konieczności unikania przez nich innych zajęć, o wadze uczciwej i pilnej pracy oraz znaczeniu, jakie ma dobór właściwego towarzystwa ${ }^{53}$. Ostrzegano, by unikali nadętości, zarozumiałości, gburowatości, „napuszenia” i skrytości, a przede wszystkim ,przywar nikczemnych i niegodnych" 54 .

Za szczególnie uwłaczające godności nauczycieli uznawano zakulisowe zabiegi o awanse, posady i przyznawanie ich ludziom, którzy na to nie zasługują. To rodziło frustrację doświadczonych i odpowiednio merytorycznie przygotowanych pedagogów, jednak należało pamiętać, że „wyższą od tego jest praca dla dobra kraju, poświęcenie

${ }^{50}$ H. Hoffman, Najważniejsze zadanie szkoty ludowej, „Szkoła” 1900, nr 4, s. 25-26, nr 5, s. 34-35.

${ }_{51}$ T. Hałas, W jaki sposób będzie nauczyciel kierował lekturą domowa uczniów?, „Szkoła” 1896, nr 8-9, s. 64-65. Szerzej na ten temat m.in.: A. Wałęga, Rodziny polskie wobec wyzwań i zagrożeń I połowy XX wieku (w świetle „, Szkoty”), „Wychowanie w rodzinie” 2016 (t. 14), nr 2, s. 209-230.

52 Szerzej na ten temat A. Wałęga, Dziedzictwo polskiej teorii i praktyki pedagogicznej na kartach ,,Szkoty”, w: Polskie dziedzictwo pedagogiczne - idee i instytucje, red. J. Falkowska, Pedagogika Toruńska, t. 7, Toruń 2016, s. 59-75.

53 E. Petryka, Szkoła i nauczyciel, „Szkoła” 1873, nr 13, s. 98-102.

54 J. Chmielewski, Jakie sa przymioty dobrego nauczyciela, op. cit., s. 137-139; idem, W jaki sposób może się nauczyciel, op. cit., s. 2-4. 
się dla ogółu" ${ }^{55}$. Przypominano, że jedynie wewnętrzne przymioty charakteru nauczyciela decydują o szacunku do niego; do tych cech zaliczano ,wiedzę, nieskazitelność charakteru, sumienność, obok tych niezbędnych form towarzyskich, znamionujących człowieka dobrze wychowanego, bez których chyba wychowawca obejść się nie może" ${ }^{56}$. Trzeba zatem pracować nad wychowaniem młodego pokolenia tak, by o kolejnych wychowankach nie mówiono „ci także mieli złych nauczycieli”.

\section{Próby usystematyzowania doświadczeń starszych kolegów}

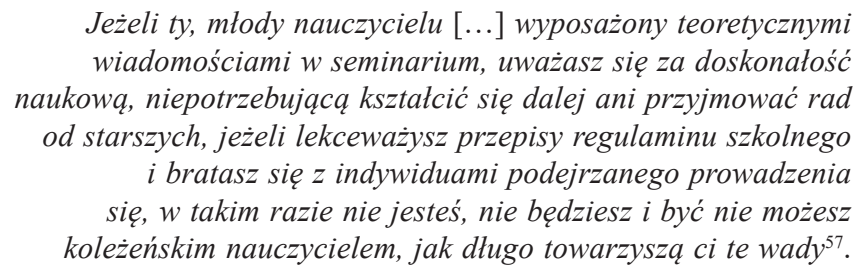

Takie apele do młodych nauczycieli oraz kierowane do nich różnorodne wskazówki zawodowe spotykamy na łamach „Szkoły” bardzo często. Niekiedy przybierały one syntetyczną formę i stanowiły próbę podsumowania doświadczeń starszych stażem kolegów. W 1885 r. Karol Falkiewicz, geograf, doświadczony nauczyciel szkół ludowych, szkół ćwiczeń oraz seminariów nauczycielskich ${ }^{58}$ opublikował kilka tekstów, które łączył podtytuł pierwszego z nich Poczatkujacym nauczycielom na drogę $e^{59}$. Podkreślał $\mathrm{w}$ nich znaczenie umiejętności zachowania taktu i godności osobistej w pracy pedagogicznej, także wobec kolegów z pracy. Zwracał uwagę na różnice dotyczące akceptacji pewnych zachowań w środowiskach wiejskich i miejskich oraz u nauczycieli i nauczycielek. Pamiętając o tych kwestiach, pedagodzy nie mieli jednak unikać nawiązywania stosunków towarzyskich, wręcz przeciwnie, Falkiewicz zalecał je jako doskonałą okazję do wzbogacenia doświadczeń życiowych. Zachęcał, by pedagodzy wspierali swoje starania w tym zakresie i wspólnie starali się tworzyć atrakcyjną towarzysko grupę dla innych osób.

55 Idem, O idealiźmie w życiu nauczycielskim, „Szkoła” 1888, nr 3, s. 18.

${ }^{56}$ Jak zdobyć powage i szacunek dla stanu nauczycielskiego?, „Szkoła” 1897, nr 43, s. 475.

57 S. Zabierzowski, O koleżeństwie, „Szkoła” 1889, nr 35, s. 337.

${ }^{58}$ Biogram Falkiewicza zamieszczony jest w pracy A. Meissnera, Spór o duszę, op. cit, s. 123.

${ }^{59}$ K. Falkiewicz, Nauczyciel na straży instytucji szkolnych. Początkujacym nauczycielom na drogę, ,Szkoła” 1885, nr 1, s. 1-2; idem, O obowiązu koleżeństwa między następcą a poprzednikiem w szkole, „Szkoła” 1885, nr 2, s. 9-11; idem, Luźne uwagi o przestrzeganiu form zewnętrznych, „Szkoła” 1885, nr 11, s. 83-85; idem, Parę uwag nad stosunkami towarzyskimi, „Szkoła” 1885, nr 36, s. 297-299. 
Rok później stały współpracownik pisma Józef Chmielewski, nauczyciel seminarium w Tarnowie oraz krajowy inspektor szkolny ${ }^{60}$, sformułował „Dwanaście artykułów nauczyciela ludowego". Zawierały one podstawowe wskazówki umożliwiające właściwe wykonywanie tego zawodu w warunkach wiejskich. Ich autor zwracał uwagę na takie aspekty, jak: bezwzględna reguła solidnego merytorycznego przygotowywania się do każdej lekcji (gdy nie jest ona przestrzegana, znika sens pojawiania się nauczyciela w pracy), przestrzegania planu lekcji i programu nauczania, poczucie odpowiedzialności za szkołę i uczniów („Bądź zawsze pierwszy w szkole, a wychodź z niej ostatni”) oraz życzliwy, uprzejmy i przyjacielski stosunek wobec uczniów, bez nadmiernej surowości i niedostępności. Nauczyciel musi cały czas pamiętać, że głównym celem wszystkich jego działań jest rozwój wychowanków, ich umoralnienie, uczynienie z nich jak najlepszych ludzi. Zaleca mu unikanie kar i napomnień (o ile nie jest to możliwe, zaleca cierpliwość, wyrozumiałość, umiar, głęboki namysł i ojcowską sprawiedliwość), gdyż ich nadmierne stosowanie cechuje złych nauczycieli. Dobry wychowawca dba o to, by dzieci wciąż miały interesujące zadania do wykonania, nie zanudza ich oraz zdaje sobie sprawę, że ciągła praca sprzyja zachowaniu spokoju w klasie. Ważne jest oczywiście także powołanie pedagogiczne („przejmuj się do głębi zawodem swoim”), osobisty wzór nauczyciela, jego działalność pozaszkolna na rzecz lokalnej społeczności oraz świadomość potrzeby ciągłego samokształcenia i doskonalenia zawodowego ${ }^{61}$.

W tym samym roku wskazówki dla młodszych kolegów sformułował także Mieczysław Baranowski, doświadczony już wówczas nauczyciel seminariów nauczycielskich i związanych z nimi szkół ćwiczeń ${ }^{62}$, zwracając szczególną uwagę na błędy popełniane przez początkujących nauczycieli. Podnosił m.in. takie kwestie, jak wdrażanie dzieci do czystości, w tym celu każdy pedagog miał dbać o schludny wygląd swego biurka i własnego stroju, przyzwyczajanie do skupienia, powagi i okazywania szacunku m.in. w czasie modlitwy czy podczas witania gości odwiedzających szkołę. Kierował też do adeptów tego zawodu wiele szczegółowych wskazówek metodycznych ${ }^{63}$.

Kolejną tego typu próbę podjął w 1895 r. Bronisław Trzaskowski, emerytowany dyrektor gimnazjum, znany działacz Towarzystwa Pedagogicznego ${ }^{64}$. Pisząc o powin-

${ }^{60}$ M. Skorzepianka, Chmielewski Józef, w: Polski Stownik Biograficzny, t. 3, Kraków 1937, s. 325-326; A. Meissner, Spór o duszę, op. cit., passim.

61 J. Chmielowski, Dwanaście artykułów nauczyciela ludowego, „Szkoła” 1886, nr 22, s. 170.

${ }^{62}$ K. Bruchnalski, Baranowski Mieczysław, w: Polski Słownik Biograficzny, t. 1, Kraków 1935, s. 282; J. Potoczny, Pedagogiczne wyznania Mieczysława Tytusa Baranowskiego, w: Galicja i jej dziedzictwo, t. 9: Biografie pedagogiczne. Szkice do portretu galicyjskiej pedagogii, red. C. Majorek, J. Potoczny, Wyd. WSP w Rzeszowie, Rzeszów 1997, s. 103-110.

${ }_{63}$ M. Baranowski, Jakich błędów często w szkole popetnianych każdy nauczyciel, a zwłaszcza początkujący najbardziej powinien się wystrzegać?, „Szkoła” 1886, nr 26, s. 201-201, nr 27, s. 210-211, nr 28, s. 220221.

${ }^{64}$ A. Meissner, Bronisław Trzaskowski (1824-1906), w: Studia z dziejów oświaty XVIII-XX wieku, red. M. Chamcówna, Wydawnictwo Uniwersytetu Wrocławskiego, Wrocław 1993, s. 67-79. 
nościach nauczyciela, zwracał uwagę na to, że „odnoszą się [one - A.W.] do jego osoby, do jego uczniów i ich rodziców, do współpracowników i przełożonych, wreszcie do gminy, w której istnieje szkoła"65. Jako próg dojrzałości do obejmowania samodzielnych posad wyznaczał 30 rok życia, oceniał bowiem, że dopiero wówczas człowiek nabiera odpowiedniego doświadczenia i osiąga właściwy poziom dojrzałości intelektualnej (na marginesie warto dodać, że w 1869 r. ten sam autor dopuszczał obejmowanie tych posad przez osoby, które ukończyły 24 rok życia) ${ }^{66}$. Nauczyciel miał być oczywiście odpowiednio merytorycznie i praktycznie przygotowany do wykonywania swojej pracy, pamiętać o samokształceniu oraz uczyć się od starszych kolegów. Wśród jego zadań Trzaskowski wymienił też aktywne uczestnictwo w życiu gminy, ojcowski stosunek do wychowanków, dobre relacje z rodzicami, Kościołem i władzami szkolnymi. Trzaskowski przypominał, że pedagogom nie wolno izolować się od społeczności pośród której żyją i pracują, powinni oni nawiązywać różnorakie stosunki towarzyskie:

Nie należymy bowiem do tych, co chcą z nauczyciela zrobić mnicha. Nauczyciel wiejski należy do ludu; z nim ma on żyć i dzielić jego radości i cierpienia i nie potrzeba wcale ustanawiać dla niego osobnego kodeksu moralności. Ale tego mamy prawo po nim żądać, aby każdy jego krok znamionowała powaga, takt i przyzwoitość ${ }^{67}$.

Upominał też, by odróżnić ideał nauczyciela od konkretnych reprezentantów tego zawodu, zalecał „Ceńmy więc wysoko swój zawód, ale myślmy nisko o sobie”68.

\section{Szczegółowe wskazówki wychowawcze - karność i umoralnianie}

W 1898 r. na kartach „Szkoły” opublikowano uszczegółowione wskazówki dotyczące możliwości wywierania przez nauczyciela pozytywnego wpływu na kształtowanie się charakteru uczniów. Przedstawiono je w dziewięciu punktach, rozpoczynając od konieczności posiadania przez samego pedagoga silnego i niezłomnego charakteru opartego na religii, moralności i patriotyzmie i zdolnego do zaszczepiania tych wartości w młodym pokoleniu. Miał on uosabiać wszelkie dobro, być grzecznym i życzliwym i porywać tym swoich uczniów, przyzwyczajając ich do podobnej postawy. Cenił porządek, rzetelność, sumienność i szacunek wobec innych, ale i wobec samego siebie,

${ }^{65}$ B. Trzaskowski, O powinnościach nauczyciela, a w szczególności nauczyciela wiejskiego, „Szkoła” 1895 , nr 4, s. 45-46, nr 5, s. 62-63.

${ }^{66}$ Idem, Seminaria nauczycielskie i ustawa obowiąująca Królestwo Galicji i Lodomerii z Wielkiem Księstwem Krakowskiem o seminariach nauczycielskich, „Szkoła” 1869, nr 28, s. 22.

${ }^{67}$ Idem, O powinnościach nauczyciela, op. cit., s. 63.

${ }^{68}$ Ibidem, nr 4, s. 46. 
unikać lekkomyślności, lenistwa, zachowań niemoralnych, faworyzowania i braku obiektywizmu ${ }^{69}$.

Rok później na łamach pisma instruowało, w jaki sposób poprawić efektywność wychowania moralnego uczniów w szkole ${ }^{70}$. W tym celu nakładano na nauczycieli obowiązek wnikliwego rozpoznania indywidualności, usposobienia i obyczajów uczniów oraz realiów ich życia pozaszkolnego rodzinnego (tu zalecano częste życzliwe i pełne szacunku kontakty z rodzicami) i rówieśniczego. Pedagoga miała przede wszystkim cechować wzmożona czujnośćc ${ }^{71}$ oraz wzorowa postawa oparta na gruntownej wiedzy, świadomości powołania i obowiązków pedagogicznych, sprawiedliwości, łagodności, uprzejmości i konsekwencji oraz niezłomności moralnej. To wszystko miało ułatwiać utrzymanie właściwej karności przy użyciu dostosowanych do danej sytuacji środków, gdyż „nauczyciel nieumiejący utrzymać karności to nieszczęśliwy kaleka pedagogiczny"72.

Problem karności szkolnej stanowił niejednokrotnie temat szczegółowych rozważań. Podejmowano go już w latach 70. XIX w. Nawiązując wyraźnie do zaleceń Johna Locke'a, apelowano, by unikać zbyt radyklanych kar, przypominano, że już sama forma spojrzenia na ucznia wyrażająca zdumienie lub niechęć czy wstręt może być karą, podobnie jak milczenie czy brak pochwał ${ }^{73}$. Poza powtarzającymi się zaleceniami, by nauczyciel rzeczywiście był dla wychowanków najlepszym wzorem do naśladowania (,,i wtedy, kiedy go dzieci widzą, i wtedy, kiedy go nie widzą, wtedy kiedy go słyszą, i kiedy go nie słyszą" "74), i dążył do osiągnięcia postawy J.H. Pestalozziego, pojawiały się konkretne wskazówki w tym zakresie. Definiowano i uzasadniano wówczas, na czym polega posłuszeństwo, opanowanie, konsekwencja czy sprawiedliwość. Zalecano, by nauczyciel nie dążył do uzyskania bezwzględnego „ślepego” posłuszeństwa, lecz zabiegał o „posłuszeństwo rozumne, oparte na zasadach religijno-moralnych, któremu wychowanek ochoczo, chętnie i dobrowolnie się poddaje"75.

Umiejętność panowania nad własnymi reakcjami emocjonalnymi powinna charakteryzować każdego nauczyciela, albowiem:

${ }^{69}$ J. Jachimowski, W jaki sposób szkoła działać będzie korzystnie na rozwój charakteru swoich uczniów?, „Szkoła” 1898, nr 6, s. 52-53, nr 7, s. 61-62.

${ }^{70}$ M. Jakimowski, Na jakie przeszkody natrafia moralne wychowanie młodzieży szkolnej i jakimi środkami można je usunąć?, „Szkoła” 1899, nr 23, s. 217-219, nr 24, s. 231-233.

71 Także inni autorzy pisali o zaletach bacznej obserwacji dzieci: „Wzrok posiada dziwną potęgę. Za pomocą niego można panować nad bezrozumnym, drapieżnym zwierzęciem. Za pomocą wzroku więc nauczyciel najlepiej potrafi utrzymać karność w szkole i opanować niesforne, zwykłe żywszej naturze malców wybryki. Jedno bystrzejsze spojrzenie sprowadzi dziecko z błędnych torów na dobra drogę. Gdzie nauczyciel wiele nie dowidzi, nie dosłyszy, tam i kar więcej potrzebuje i skutek pracy jego słabszy” (S. Pallan, op. cit., s. 36).

${ }^{72}$ M. Jakimowski, op. cit., s. 232-233.

${ }^{73}$ W. Miłkowski, O karach szkolnych Kilka rad dla nauczycieli szkół początkowych, „Szkoła” 1873, nr 17, S. $129-131$.

${ }^{74}$ M. Haraszkiewicz, Osobistość nauczyciela podwalina karności szkolnej, „Szkoła” 1887, nr 5, s. 35.

75 Ibidem, s. 36. 
wybuchy różnych namiętności: gniewu, zemsty, nienawiści, radości z cudzego nieszczęścia poniżają każdego człowieka, ale u nikogo nie pociągają za sobą takich skutków, jak u nauczyciela, ten bowiem szkodzi nie tylko sobie, ale i młodszemu pokoleniu, przez co rujnuje podstawę społeczeństwa ${ }^{76}$.

W przypadku konsekwencji zaznaczano, że cechujący się nią nauczyciel nie potrzebuje wielu komunikatów do osiągnięcia odpowiednich wyników, unika stosowania gróźb, wyzwisk, z rozwagą formułuje komunikaty wobec uczniów i unika czczych deklaracji. Bycie sprawiedliwym określano jako zadanie wymagające od pedagoga znacznego wysiłku związanego przede wszystkim z dokładnym poznaniem wszystkich okoliczności, które wpłynęły na niewłaściwe zachowanie wychowanków i unikaniem pochopnych osądów i decyzji ${ }^{77}$. Sugerowano, że nauczyciel może przyjąć wobec swoich uczniów dwa stanowiska: postrachu i terroryzmu lub łagodności i humanizmu. Ta druga była zalecana jako skuteczna wychowawczo, obejmowała ona wzajemną życzliwość oraz ojcowskie traktowanie dzieci. Akcentowano, że to stanowisko ma wiele zalet ${ }^{78}$.

„Suma tych przepisów brzmi: umiej przy całej miłości i uprzejmości swojej zachować swoją powagę [podkr. - A.W.] z całą gorliwością i starannością"79. Nie wolno okłamywać uczniów, składać obietnic, których nie będzie można dotrzymać. Trzeba stanowczo egzekwować decyzje dotyczące przestrzegania regulaminów oraz przykrych konsekwencji wynikających z przekroczenia zawartych w nich zasad. Do najważniejszych zadań wychowawcy należą działania prewencyjne: „Wskutek wiecznej groźby, ciągłej kłótni i łajania, traci wielu nauczycieli i rodziców szacunek i powagę u dzieci. Zakazuj mało, lecz przestrzegaj ciągle!" ${ }^{10}$. Powagę nazywano zresztą ,perłą w diademie nauczyciela" ${ }^{" 1}$, podobnie traktowano takt pedagogiczny - jako nieodzowny element charakterystyki nauczyciela ${ }^{82}$.

\section{Relacje $\mathbf{z}$ domem rodzinnym uczniów a przykład rodzin nauczycielskich}

Temat ten podjęła „Szkoła” już w pierwszym roku swojego funkcjonowania ${ }^{83}$. S. Sobieski pisał wówczas:

\footnotetext{
${ }^{76}$ Ibidem, nr 6, s. 43.

77 Ibidem, s. 44.

${ }^{78}$ E. Reben, Stanowisko nauczyciela wobec uczniów, „Szkoła” 1871, nr 17, s. 129-130.

79 J. Chmielewski, Lagodna surowość, „Szkoła” 1881, nr 11, s. 85.

${ }^{80}$ Ibidem.

${ }^{81}$ M. Schlesinger, W jaki sposób można utrzymać karność w szkole ludowej?, „Szkoła” 1882, nr 49, s. 388.

82 M. Haraszkiewicz, Osobisty wpływ nauczyciela na wychowanie młodzieży, „Szkoła” 1890, nr 4, s. 35.

${ }^{83}$ Szerzej na ten temat: A. Wałęga, O zadaniach wychowawczych rodziny. Koncepcje wspótpracowników czasopisma ,,Szkoła”, „Wychowanie w Rodzinie” 2014 (t. 10), nr 2, s. 137-158; eadem, Rodziny polskie wobec
} 
Lud nasz prosty nie ma żadnego wychowania: przez dobre wychowanie swych dzieci sam nabędzie lepszego wychowania, bo to jest rzeczą niezaprzeczalną, że szkoła pośrednio wpływa na dom i rodzinę i powinna wyrównywać i wyrównywa istotne braki domowe pod tym względem, a tym samym wpływa wychowawczo i na starszych ${ }^{84}$.

Podkreślał, jak ważne są właściwe relacje z domem rodzinnym uczniów. Przypominał, że podstawowym zadaniem nauczyciela jest dbałość o zainteresowanie rodziców sprawami szkoły m.in. poprzez zachęcanie całych rodzin do uczestnictwa w zajęciach szkółki niedzielnej. Udzielał też swoim kolegom cennych rad w tym zakresie. Opierały się one na cierpliwości i uprzejmości względem rodziców, którzy mogą znacząco pomóc w poznaniu charakteru ucznia oraz unikaniu otwartego negowania panujących w rodzinach zasad i obyczajów. Jeśli wymagały one zmian, zalecał ostrożne i stopniowe działania: ,zawsze zostawać w przyjacielskim z rodzicami stosunku, wystrzegać się od „sekowana” itd. - i chyba w najostateczniejszym razie oprzeć się środkom przewrotnym lub życzeniom nagannym domu" 85 .

Podobnie Bronisław Trzaskowski zalecał, by nauczyciel wobec uczniów postępował, jak przystało na ,zastępcę i mandatariusza” rodziców w sposób ojcowski, z rodzicami radził nawiązywać bliższe stosunki ale jednocześnie unikać wszelkich przejawów poufałości ${ }^{86}$.

Także inni autorzy opisywali okoliczności sprzyjające nawiązywaniu kontaktów z rodzicami, odwoływali się zarówno do tych wymienianych w przepisach (jak zapisywanie dziecka do szkoły, usprawiedliwianie jego nieobecności, wyznaczanie surowszych kar), jak i proponując szerszą aktywność w bibliotekach, kółkach rolniczych, gospodach z czytelniami czy ogrodach ${ }^{87}$. Nauczyciel powinien w tym celu doskonale znać zasady funkcjonowania gminy, dbać o jej interesy i być wzorem dla mieszkańców. Miał utrzymywać poprawne relacje z rodzicami, zawsze chętnie udzielać im porad wychowawczych oraz pamiętać o tym, by nie ograniczać swych obowiązków jedynie do nauczania ${ }^{88}$. Proponowano nawiązywanie stosunków towarzyskich z miejscową inteligencją. Uświadamiano też pedagogów, że z ludem należy rozmawiać w pewien określony sposób, m.in. poprzez stosowanie obrazowych i anegdotycznych porównań oraz cierpliwość przy wysłuchiwaniu ich żalów i pretensji. Zalecano przestrzeganie ważnych zwłaszcza dla mieszkańców wsi

wyzwań i zagrożeń I połowy XX wieku (w świetle „Szkoły”) „Wychowanie w rodzinie” 2016 (t. 14), nr 2, s. 209-230. S. 154 .

${ }^{84}$ S. Sobieski, Czego mamy obecnie żądać po nauczycielu szkół ludowych, „Szkoła” 1868, t. 1, nr 3,

${ }^{85}$ Ibidem, nr 4, s. 233.

86 B. Trzaskowski, O powinnościach nauczyciela, op. cit., nr 4, s. 45-46, nr 5, s. 62-63.

${ }^{87}$ A. Stiasny, Czy i jak może nauczyciel wobec obowiązujących ustaw szkolnych utrzymać łączność między szkoła a domem? (Rzecz odczytana przez kierownika 2 klasowej szkoly w Woli Wadowskiej na posiedzeniu kółka pedagogicznego w Radomyślu), „Szkoła” 1883, nr 42, s. 332-334. s. $9-11$.

${ }^{88}$ J. Chmielewski, W jaki sposób może się nauczyciel przyczynić do podniesienia szkót, op. cit., nr 2, 
form religijnych oraz wyrażanie zainteresowania sprawami gospodarskimi ${ }^{89}$. Uczulano, że jeżeli w ciągu dwóch lat pracy nie uda się pozyskać przychylności dzieci i rodziców, trzeba poddać swoje zachowanie wnikliwej autorefleksji1 .

Wskazywano na potencjalne przyczyny konfliktów na linii szkoła-dom: „Ileż to razy szkoła wchodzi w kolizję z domem rodzicielskim, gdy w celach wychowawczych, z powodu zaniedbania obowiązków, musi dotykać niemile w uczuciach miłości rodzicielskiej, a jeszcze częściej i dotkliwiej w ich dumie i próżności nieograniczonej"91. Ponieważ w ocenie wielu autorów szkoła w znacznym zakresie przejęła obowiązki wychowawcze rodziny, nauczyciel powinien stanowić dla uczniów wzór osobowy, zachowywać karność, cechować się stanowczą i rozważną konsekwencją w działaniu, obowiązkowością oraz unikać wyręczania się uczniami.

Przypominano, że rodzice nie tylko w większości przypadków nie współpracują ze szkołą, ale wręcz niweczą wychowawcze wysiłki nauczycieli. Jednak pomimo tak pesymistycznej diagnozy sytuacji uczulano pedagogów, by nie rezygnowali z kolejnych działań i prób przekonania rodzin do idei edukacji: „Pamiętajmy, że serce rodzicielskie, chociaż pod zgrzebną koszulą, bije mocno dla dziecka; pojmie instynktem gdzie chodzi o jego dobro i wnet się znajdzie wdzięczność, choćby niema"92.

Poszukiwano przyczyn zaniedbań wychowania domowego, w rodzinach zamożniejszych upatrywano ich w „sztabie” guwernerów i opiekunek, u biednych w zmaganiach w codziennej walce o byt. Jako główny obowiązek nauczyciela wskazywano przede wszystkim określenie źródła demoralizacji i rozstrzygnięcie, czy wina leży w rodzinie, czy w towarzystwie wychowanka. Sugerowano, że zwykle problem stanowi dom rodzinny, pastwisko oraz karczma. Władze gminy miały wspierać nauczycieli, którym nie wolno było stosować kar fizycznych, np. zakazując młodzieży wstępu do karczmy niestety wielu mieszkańców wsi nie dostrzegało w tym zagrożenia ${ }^{93}$.

Młodzi nauczyciele i w tym zakresie otrzymywali na łamach „Szkoły” cenne rady. Przykładowo w 1877 r. Andrzej Józefczyk kierujący seminarium nauczycielskim męskim w Krakowie sygnalizował, że szkoła nie jest w stanie zniwelować wszystkich błędów i zaniedbań wychowawczych domu rodzinnego. Nauczyciele nie powinni jednak tracić zapału i oddziaływać na uczniów poprzez osobisty przykład ${ }^{94}$. Takich porad

${ }^{89}$ K. Falkiewicz, Nauczyciel a lud wiejski, „Szkoła” 1886, nr 11, s. 81-82, nr 12, s. 89-91, nr 13, s. 97-98.

90 M. Haraszkiewicz, Osobistość nauczyciela, op. cit., s. 35-36.

91 S. Spitzer, W jaki sposób wptywać może szkoła na wzbudzenie u dzieci poczucia obowiązku, „Szkoła” 1899 , nr 22, s. 212.

92 J. Wawro, O potrzebie pracy nauczyciela poza obrębem izby szkolnej nad oświata młodszego i starszego pokolenia ludu, „Szkoła” 1900, nr 3, s. 18-19, nr 5, s. 26. Cytat s. 18.

93 A. Rotyński, O obowiązu czuwania nad zachowaniem się młodzieży poza szkoła, „Szkoła” 1900, nr 9-10, s. 71-72; M. Jakimowski, Na jakie przeszkody natrafia moralne wychowanie młodzieży szkolnej $i$ jakimi środkami można je usunać, ,Szkoła” 1899, nr 2, s. 217-219, nr 24, s. 231-233.

94 A. Józefczyk, Listy do przyjaciela wstępującego w zawód nauczycielski, „Szkoła” 1877, nr 39, s. 373374, nr 40, s. 381-382, nr 41, s. 393-395, nr 42, s. 401-403. 
udzielali także inspektorowie szkolni, m.in. Józef Chmielewski. W jego ocenie sukces w pracy zawodowej nauczyciela ludowego jest w znacznej mierze uzależniony od pozyskania zaufania rodziców i całej gminy ${ }^{95}$. Poszukiwano przyczyn demoralizacji młodzieży wiejskiej i właściwych sposobów reakcji profesjonalnych pedagogów ${ }^{96}$

W tym też kontekście zwracano baczną uwagę na wywiązywanie się przez nauczycieli z obowiązków ojcowskich. Apelowano, by ich rodziny i dzieci stanowiły wzór do naśladowania. Zaznaczano, że dzieci nauczyciela są wizytówką jego skuteczności wychowawczej, wskazywano na najczęściej popełniane przez nich zaniedbania w tym zakresie m.in. zbyt daleko posuniętą swobodę i wyjątkowe przywileje ${ }^{97}$.

Ważne było też, by pedagog miał ustabilizowane i szczęśliwe życie osobiste, by rozważnie wybrał kandydatkę na żonę ${ }^{98}$. „Jeśli żona ma jaką wadę kardynalną, jest skąpą albo rozrzutnicą, kokietą albo niedbałą, sekutnicą albo prostaczką, to pewnie każdy z tych błędów cieniem długim zaznaczy się i w szkole, każdą domową nieprzyjemność odpokutują gorzko uczniowie"99. Podkreślano bowiem, że przy ocenie skuteczności oddziaływania pedagoga na powierzone jego opiece dzieci i ich rodziny często największą rolę odgrywa właśnie jego postawa i zachowanie poza szkołą. Uczniowie i ich rodzice bacznie go obserwują „,Biada nauczycielowi o którego czynach i biegu życia w familijnych kółkach w gminie szkolnej toczą się rozmowy z przyganą, wstrząsaniem ramionami i kiwaniem głowy, którego rodzice nie obdarzają tym szczerym i rzetelnym szacunkiem"lo0.

\section{Aktywność pozaszkolna pedagogów}

Często podejmowanym na łamach „Szkoły” tematem był stosunek do dodatkowych form zatrudnienia nauczycieli ludowych. Stawiano wówczas pytania o to, czy należy pozwolić, by reprezentanci tego zawodu szukali dodatkowych źródeł dochodu. Odpowiedzi były zróżnicowane. W 1868 r. S. Sobieski zalecał unikać dodatkowych zatrudnień, zwłaszcza takich, które pozostają w widocznym konflikcie z powagą zawodu. Tymczasem nauczyciel ludowy w Galicji w II połowie XIX w. często był także „organistą, diakiem, pisarzem i Bóg wie czym”101. W tamtym okresie pisali o tym

95 J. Chmielewski, W jaki sposób może się nauczyciel przyczynić do podniesienia szkół w gminie?, „Szkoła” 1880 , nr 1, s. 2-4.

96 A. Kurzbauer, Nieco o przyczynach moralnego zepsucia młodzieży wiejskiej, tudzież o sposobach zaradzenia złemu (Rzecz z powodu okólnika RSK), „Szkoła” 1899, nr 19, s. 181-183, nr 20, s. 191-193.

${ }^{97}$ Synowie nauczycielscy - głos z prowincji, „Szkoła” 1884, nr 2, s. 9-10.

98 A. Bieroński, Rodzina nauczyciela jako czynnik uszlachetniajacy lud, „Szkoła” 1900, nr 37, s. 301-302, nr 38, s. 310-311.

${ }_{99}$ M. Haraszkiewicz, Osobisty wplyw nauczyciela na wychowanie młodzieży, „Szkoła” 1890, nr 4, nr 5,

100 J. Chmielewski, O zaufaniu dzieci do nauczyciela (podtug Salkmanna), „Szkoła” 1879, nr 1, s. 1-2.

101 S. Sobieski, op. cit., s. 156. 
także inni autorzy. Jako jedyne akceptowane, poza szkolnymi, obowiązki nauczyciela, wymieniali obowiązki obywatelskie ${ }^{102}$. Zachęcano zatem, by wdrażać do nich uczniów, niektórzy podawali nawet przykłady USA, gdzie w szkołach czytano uczniom konstytucję $^{103}$. W celu podniesienia poziomu życia nauczycieli zalecano im sadownictwo, pszczelarstwo czy hodowlę jedwabników ${ }^{104}$. W ocenie wielu współpracowników pisma praca organisty czy pisarza gminnego obniżała rangę i godność zawodu nauczyciela, odciągała od pracy pedagogicznej i odbierała szacunek ludzi. Przykładowo gdy bywał on organistą, to zwyczajowo po pogrzebach czy ślubach zapraszano go do karczmy, dodatkowo uzależniał się także wówczas od proboszcza ${ }^{105}$.

Zdarzały się jednak i zdania przeciwne. W 1883 r. Alojzy Stiasny deklarował, że jeżeli nauczyciel potrafił pogodzić zadania pisarza gminnego z pracą $\mathrm{w}$ szkole, to powinien w ten sposób pomagać lokalnej społeczności. Nie zgadzał się z wprowadzonym w 1873 r. zakazem łączenia tych dwóch stanowisk ${ }^{106}$. Warto w tym miejscu przypomnieć, że oddział łańcucki Towarzystwa Pedagogicznego zgłosił wówczas wniosek o umożliwienie nauczycielom powrotu do tych dodatkowych obowiązków ${ }^{107}$. Przeciwnikiem dodatkowych obowiązków dla nauczycieli nie był także Bronisław Trzaskowski. W 1895 r. zezwalał na nie, o ile nie przeszkadzały w wykonywaniu pracy pedagogicznej ${ }^{108}$. Przestrzegał jednak wyraźnie przed nadmiernym angażowaniem się w życie polityczne, a zainteresowanym tą dziedziną osobom radził, by wcześniej porzuciły aktywność wychowawczą i nauczycielską. Trzeba jednak podkreślić, że w $1869 \mathrm{r}$.

102 P. Święcicki, Stanowisko nauczyciela wiejskiego, „Szkoła”1870, nr 36, s. 561.

103 Ibidem, s. 561-565.

${ }^{104} \mathrm{~K}$. Freund, Jakim sposobem nauczyciel ludowy wlasna praca swój byt materialny polepszyć może, „Szkoła” 1872, nr 51, s. 402-403.

105 Por. E. Gabryelski, Nauczyciel-organista, „Szkoła” 1869, nr 9, s. 136-140. Wspomina o tym także E. Petryka, Jakie przymioty powinien posiadać dobry nauczyciel? (odczytano na walnym zgromadzeniu pedagogicznym w Chrzanowie dnia 12 kwietnia 1870 r.), ,Szkoła” 1870, nr 18, s. 273-278, nr 19, s. 289-293; idem, Szkoła i nauczyciel, „Szkoła” 1873, nr 13, s. 98-102 czy S.R., Nauczyciel powinien wszystkie swoje sity swojemu zawodowi poświęcić, „Szkoła” 1872, nr 40, s. 313-314, nr 41, s. 321-322; A. Pragłowski, Jak pogodzić stanowisko nauczyciela z obowiązami pisarza gminnego lub organisty? (Rzecz czytana na walnym zgromadzeniu Towarzystwa Pedagogicznego w Gorlicach), „Szkoła” 1873, nr 16, s. 123-127; A. Stiasny, Czy i jak może nauczyciel wobec obowiąujących ustaw szkolnych utrzymać łączność między szkołą a domem?, „Szkoła” 1883, nr 42, s. 332-334; B. Trzaskowski, O powinnościach nauczyciela, op. cit, nr 4, s. 45-46, nr 5, s. $62-63$.

106 Sejm Krajowy przyjął wówczas ustawę o stosunkach prawnych stanu nauczycielskiego, w której m.in. odebrano nauczycielom możliwość wykonywania dodatkowych obowiązków, zwłaszcza gdy zagrażały one właściwemu wypełnianiu ich pracy pedagogicznej czy narażały na szwank powagę zawodu nauczyciela. Już wcześniej, bo od lat 50. XIX wieku podejmowane były próby zwalniania nauczycieli z pracy na rzecz gmin, dworów czy kościoła. Szerzej na ten temat C. Majorek, Urzędowa koncepcja ideału nauczyciela szkoły ludowej w Galicji doby autonomicznej, „Rocznik Komisji Nauk Pedagogicznych” 1970, t. 10, s. $210-212$.

107 Patrz: A. Stiasny, Czy i jak może nauczyciel wobec obowiązujących ustaw szkolnych utrzymać łaczność między szkoła a domem?, „Szkoła” 1883, nr 42, s. 332-334.

108 Patrz: B. Trzaskowski, O powinnościach nauczyciela, a w szczególności nauczyciela wiejskiego, op. cit., nr 4, s. 45-46, nr 5, s. 62-63. 
Trzaskowski deklarował: „Czas by już był, aby urząd nauczyciela od zatrudnienia organisty lub diaka raz na zawsze odłączono"109.

Zadaniem pedagogów miała być ciągła troska o rozwój i dobro szkoły oraz jej godne i honorowe reprezentowanie na zewnątrz, nie wolno im wykorzystywać swojego stanowiska społecznego do jakichkolwiek form agitacji (politycznych, religijnych, narodowościowych czy społecznych). Mogli natomiast głosować, wspierać organizacje i towarzystwa dobroczynne, pracować czynnie w radach gminnych czy powiatowych, jeżeli mieli do tego odpowiednie kompetencje oraz zapa1 ${ }^{110}$.

Społeczne i obywatelskie aspekty pracy nauczycieli często podnoszono. Proponowano, by nie ograniczali oni zakresu swoich zawodowych obowiązków do nauczania, lecz zakładali ludowe czytelnie, towarzystwa zaliczkowe (by wyeliminować tak szkodliwe zjawisko lichwy), młodzieżowe straże ogniowe, by dbali o podniesienie poziomu higieny i gospodarstw wiejskich, propagowali tak popularne w innych dzielnicach ubezpieczenia czy kółka włościańskie. Pedagodzy mieli dążyć do uszlachetniania ludu, zjednać sobie zaufanie gminy i dbać o obywatelskie wychowanie ludu, jednak przy unikaniu angażowania się w sprawy polityczne ${ }^{111}$. Zalecano im wspieranie prac Macierzy Polskiej czy Towarzystwa Oświaty Ludowej ${ }^{112}$. Tylko będąc aktywnym społecznie, żyjąc i działając dla dobra innych, nauczyciel miał szansę zmienić nastawienie społeczności wiejskiej wobec szkoły. Nie powinien przy tym zniechęcać się typową dla mieszkańców wsi awersją do edukacji, ale rozmawiać z nimi w czytelniach czy podczas sesji gminy, zaangażować się w działające na jej obszarze ochronki, a nawet towarzystwa muzyczne ${ }^{113}$.

Przypominano, że nauczycielowi nie wolno ograniczać się do pracy w szkole; powinien on być ponadto aktywnym członkiem gminy, społeczeństwa, kraju i wreszcie narodu. W czytelniach, które mógł też sam zakładać, zalecano mu organizowanie pogadanek rolniczych, historycznych czy pedagogicznych. Jego celem miało być ponadto propagowanie sądów polubownych oraz zachęcanie ludu do ubezpieczania się m.in. od gradu i pożaru. Powinien też dbać o powstanie we wsi katolickiej gospody i sklepu z podstawowym asortymentem aptecznym, zabiegać o członkostwo w radzie gminnej oraz ostrzegać rodziców przed wysyłaniem córek do pracy daleko od domu (wyraźne nawiązania do zagrożenia prostytucją) $)^{114}$.

109 Idem, Seminaria nauczycielskie i ustawa, op. cit., nr 28, s. 22.

110 S. Pallan, op. cit., s. 37.

111 T. Romanowicz, Społeczne zadania nauczyciela wiejskiego (wyklad podczas walnego zjazdu Towarzystwa Pedagogicznego w Tarnopolu), ,Szkoła” 1877, nr 32, s. 309-310, nr 33, s. 317-319, nr 34, s. 329-330, nr 35, s. 337-339, nr 36, s. 349-350, nr 37, s. 357-359, nr 38, s. 365-366.

112 F. Kozdraś, Pierwsze kroki w zawodzie nauczycielskim, „Szkoła” 1891, nr 38, s. 445-447.

${ }_{113}$ M. Borucka, Jak ma postępować nauczyciel wobec proboszcza, dworu i gminy aby pozyskać dla siebie miłość i szacunek a dla szkoły ich współdziałanie, „Szkoła” 1890, nr 21, s. 237-240; B. Trzaskowski, O powinnościach nauczyciela, op. cit., nr 4, s. 45-46, nr 5, s. 62-63.

114 S. Gonet, Działalność nauczyciela poza szkoła, „Szkoła” 1899, nr 25, s. 241-242, nr 26, s. 254-255. 
W rozważaniach poświęconych społecznej pracy pedagogów często pojawiły się opisy fatalnych warunków życia ludu wiejskiego oraz możliwości ich poprawy. Uczulano nauczycieli na charakterystyczny dla ludu głęboki konserwatyzm i niechęć wobec nowych rozwiązań, zalecano, by nie podejmować prób radykalnego wykorzeniania tych cech, bo to one umożliwiły mieszkańcom wsi zachowanie religii, kultury i tradycji ich przodków. Nauczyciel miał w tym zakresie oddziaływać siłą własnego przykładu, a raczej siłą przykładu swego wzorcowego gospodarstwa. Jeden ze współpracowników pisma, który wiele lat pracował jako lustrator kółek rolniczych, dawał młodym adeptom tego zawodu szereg cennych rad dotyczących ich pracy na roli: „Powoli niedowierzanie i lekceważenie nauczyciela rolnika znikną wobec bijących w oczy dodatnich rezultatów jego postepowania, i z czasem, naprzód poszczególni sąsiedzi, a potem większość, a z młodego pokolenia wszyscy, pójdą za jego przykładem"115. Choć uprzedzał o początkowej kpinie i pogardzie ze strony mieszkańców wsi i sugerował, że morga ziemi i obecne wynagrodzenie nauczycieli to za mało, by prowadzić wzorowe gospodarstwo, był w tym względzie optymistą.

\section{Podsumowanie}

Zaprezentowana w tekście analiza artykułów o treści pedeutologicznej zamieszczonych na kartach pisma „Szkoła” w okresie zaborów wskazuje, że nauczycielom ludowym stawiano wysokie wymagania. Miało ich wyróżniać doskonałe przygotowanie merytoryczne i metodyczne, zapał do pracy oraz umiłowanie swego zawodu i życzliwy stosunek wobec wychowanków. Do ich obowiązków oprócz rzetelnej pracy dydaktycznej i opiekuńczo-wychowawczej w szkole dodawano aktywne zaangażowanie w sprawy społeczności, w której żyli. Mieli oni podnosić nie tylko poziom wykształcenia mieszkańców poszczególnych gmin, ale także dbać o ich rozwój społeczny, obywatelski, kulturowy i gospodarczy. Zalecano, by nauczyciel ludowy w każdym aspekcie swojego życia stanowił wzór do naśladowania nie tylko dla swoich uczniów, ale dla mieszkańców całej gminy, co wymagało od niego nieustannej autorefleksji nad własnym postępowaniem. Nie ukrywano jednak przed kolejnymi adeptami tego zawodu różnorodnych trudności związanych z jego wykonywaniem, zwłaszcza w środowiskach wiejskich.

\section{Bibliografia}

\section{Źródła}

B.O., Czy zawód nauczyciela ludowego jest szczytnym i czy przykrym musi być koniecznie?, „Szkoła" 1896, nr 13, s. 114-116.

115 B. Kwiatkowski, Nauczyciel ludowy jako nauczyciel gospodarstwa wiejskiego, „Szkoła” 1896, nr 4, s. 28. 
Baranowski M., Jakich błędów często w szkole popetnianych każdy nauczyciel, a zwłaszcza początkujacy, najbardziej powinien się wystrzegać?, „Szkoła” 1886, nr 26, s. 201-201, nr 27, s. 210 211, nr 28, s. 220-221.

Baranowski M., O zadaniu szkoty ludowej i o środkach za pomoca których zadanie to można osiagnać, „Szkoła” 1890, nr 27, s. 333-337.

Bernadzikiewicz W.M., O miłości nauczyciela ku uczniom, „Szkoła” 1870, nr 22, s. 345-347.

Bieroński A., Rodzina nauczyciela jako czynnik uszlachetniający lud, „Szkoła” 1900, nr 37, s. 301302, nr 38, s. 310-311.

Borucka M., Jak ma postępować nauczyciel wobec proboszcza, dworu i gminy aby pozyskać dla siebie miłość i szacunek a dla szkoły ich współdziałanie, „Szkoła” 1890, nr 21, s. 237-240.

Bruchnalski K., Baranowski Mieczysław, w: Polski Słownik Biograficzny, t. I, Kraków 1935, s. 282.

Chlebowski S., Nauczyciel, „Szkoła” 1868, t. I, nr 1, s. 7-10.

Chmielewski J., Jak może nauczyciel pozyskać miłość i szacunek dzieci, jako też i gminy, „Szkoła” 1880 , nr 40, s. 333-334, nr 41, s. 339-342, nr 42, s. 351-352, nr 43, s. 360-362.

Chmielewski J., Jakie sa przymioty dobrego nauczyciela, „Szkoła” 1876, nr 15, s. 137-139.

Chmielewski J., Lagodna surowość, „Szkoła” 1881, nr 11, s. 84-85.

Chmielewski J., O idealiźmie w życiu nauczycielskim, „Szkoła” 1888, nr 1, s. 3-5, nr 2, s. 9-10, nr 3, s. 17-19.

Chmielewski J., O zaufaniu dzieci do nauczyciela (podtug Salkmanna), „Szkoła” 1879, nr 1, s. 1-3.

Chmielewski J., W jaki sposób może się nauczyciel przyczynić do podniesienia szkół w gminie?, „Szkoła” 1880, nr 1, s. 2-4, nr 2, s. 9-11.

Chmielowski J., Dwanaście artykułów nauczyciela ludowego, „Szkoła” 1886, nr 22, s. 170.

Chmielowski J., O zamiłowaniu w zawodzie, „Szkoła” 1880, nr 9, s. 67-69.

Chmielowski J., O idealiźmie w życiu nauczycielskim, „Szkoła” 1888, nr 1, s. 3-5, nr 2, s. 9-10, nr 3, s. 17-19.

Dobrowolski J., Kilka słów o indywidualności nauczyciela, „Szkoła” 1889, nr 9, s. 83-84.

Falkiewicz K., Luźne uwagi o przestrzeganiu form zewnętrznych, „Szkoła” 1885, nr 11, s. 83-85.

Falkiewicz K., Nauczyciel na straży instytucji szkolnych. Początkujacym nauczycielom na droge, „Szkoła” 1885, nr 1, s. 1-2.

Falkiewicz K., O obowiązku koleżeństwa między następca a poprzednikiem w szkole, „Szkoła” 1885 , nr 2, s. 9-11.

Falkiewicz K., Parę uwag nad stosunkami towarzyskimi, „Szkoła” 1885, nr 36, s. 297-299.

Falkiewicz K., Nauczyciel a lud wiejski, „Szkoła” 1886, nr 11, s. 81-82, nr 12, s. 89-91, nr 13, s. $97-98$.

Freund K., Jakim sposobem nauczyciel ludowy własna praca swój byt materialny polepszyć może, „Szkoła” 1872, nr 51, s. 402-403.

Gabryelski E., Nauczyciel-organista, „Szkoła” 1869, nr 9, s. 136-140.

Gabryelski E., O wychowaniu narodowym i o posłannictwie nauczycielstwa ludowego, „Szkoła” 1895 , nr 23, s. 297-299, nr 24, s. 310-311, nr 32, s. 417-418, nr 34, s. 438-441.

Gonet S., Działalność nauczyciela poza szkoła, „Szkoła” 1899, nr 25, s. 241-242, nr 26 s. 254255.

Hałas T., W jaki sposób będzie nauczyciel kierowat lektura domowa uczniów?, „Szkoła” 1896, nr 8-9, s. 64-65.

Haraszkiewicz M., Osobistość nauczyciela podwalina karności szkolnej, „Szkoła” 1887, nr 5, s. 35-36, nr 6, s. 43-44.

Haraszkiewicz M., Osobisty wpływ nauczyciela na wychowanie młodzieży, „Szkoła” 1890, nr 4, s. $33-35$, nr 5, s. $43-46$. 
Hoffman H., Najważniejsze zadanie szkoty ludowej, „Szkoła” 1900, nr 4, s. 25-26, nr 5, s. 34-35.

Jachimowski J., $W$ jaki sposób szkoła działać będzie korzystnie na rozwój charakteru swoich uczniów?, „Szkoła” 1898, nr 6, s. 52-53, nr 7, s. 61-62.

Jak zdobyć powagę i szacunek dla stanu nauczycielskiego?, „Szkoła” 1897, nr 43, s. 473-475.

Jakimowski M., Na jakie przeszkody natrafia moralne wychowanie młodzieży szkolnej i jakimi środkami można je usunać, „Szkoła” 1899, nr 2, s. 217-219, nr 24, s. 231-233.

Józefczyk A., Listy do przyjaciela wstępującego w zawód nauczycielski, „Szkoła” 1877, nr 39, s. 373-374, nr 40, s. 381-382, nr 41, s. 393-395, nr 42, s. 401-403.

Kozdraś F., Pierwsze kroki w zawodzie nauczycielskim, „Szkoła” 1891, nr 38, s. 445-447.

Kurzbauer A., Nieco o przyczynach moralnego zepsucia młodzieży wiejskiej, tudzież o sposobach zaradzenia złemu (Rzecz z powodu okólnika RSK), „Szkoła” 1899, nr 19, s. 181-183, nr 20, s. 191-193.

Kwiatkowski B., Nauczyciel ludowy jako nauczyciel gospodarstwa wiejskiego, „Szkoła” 1896, nr 4, s. 27-28.

Miłkowski W., O karach szkolnych Kilka rad dla nauczycieli szkół początkowych, „Szkoła” 1873, nr 16, s. 121-123, nr 17, s. 129-131, nr 18, s. 137-139.

Nowakowski F., Nauczycieli byt dobry a praca sumienna i umiejętna nieodzownym warunkiem oświaty ludu (rzecz czytana na zgromadzeniu oddziału wadowickiego Towarzystwa Pedagogicznego), „Szkoła” 1869, nr 29, s. 33-41.

Nowakowski J., Przyktad nauczyciela, „Szkoła” 1885, nr 1, s. $2-3$.

Nowakowski J., Zwyciężę! Marzenia w chwili wyboru zawodu polskiego nauczyciela-wychowawcy, „Szkoła” 1900, nr 27, s. 214-215.

Nowicki I., Zaufanie uczniów do nauczyciela, „Szkoła” 1898, nr 8, s. 70.

Pallan S., Obowiazki nauczyciela. Parafraza §32 Tyt. V Regulaminu dla szkót ludowych, „Szkoła” 1888 , nr 4, s. 25-26, nr 5, s. 36-37.

Petryka E., Jakie przymioty powinien posiadać dobry nauczyciel? (odczytano na walnym zgromadzeniu pedagogicznym w Chrzanowie dnia 12 kwietnia 1870 r.), „Szkoła” 1870, nr 18, s. 273 278 , nr 19, s. 289-293.

Petryka E., Szkoła i nauczyciel, „Szkoła” 1873, nr 13, s. 98-102.

Pragłowski A., Jak pogodzić stanowisko nauczyciela z obowiązkami pisarza gminnego lub organisty? (Rzecz czytana na walnym zgromadzeniu Towarzystwa Pedagogicznego w Gorlicach), „Szkoła” 1873, nr 16, s. 123-127.

R., Hipolit Seredyński. Wspomnienie pośmiertne, „Szkoła” 1874, nr 23, s. 197-198, nr 24, s. $206-$ 207, nr 25, s. 218-219.

Reben E., Stanowisko nauczyciela wobec uczniów, „Szkoła” 1871, nr 17, s. 129-130.

Reforma szkót i Seminaria Nauczycielskie, „Szkoła” 1870, nr 41, s. 643-644.

Romanowicz T., Społeczne zadania nauczyciela wiejskiego (wyklad podczas walnego zjazdu Towarzystwa Pedagogicznego w Tarnopolu), ,Szkoła” 1877, nr 32, s. 309-310, nr 33, s. 317319 , nr 34 , s. $329-330$, nr 35 , s. $337-339$, nr 36 , s. $349-350$, nr 37 , s. $357-359$, nr 38 , s. $365-366$.

Rotyński A., O obowiązu czuwania nad zachowaniem się młodzieży poza szkoła, „Szkoła” 1900, nr 9-10, s. 71-72.

S.R., Nauczyciel powinien wszystkie swoje sity swojemu zawodowi poświęcić, „Szkoła” 1872, nr 40, s. 313-314, nr 41, s. 321-322.

Sawczyński Z., Na czym zależy przede wszystkim skuteczne działanie nauczyciela $w$ szkole niższej czyli tak zwanej ludowej, „Szkoła” 1869, nr 1, s. 1-5, nr 2, s. 17-23.

Schlesinger M., W jaki sposób można utrzymać karność w szkole ludowej?, „Szkoła” 1882, nr 48, s. 381-382, nr 49, s. 387-389, nr 51, s. 404-406, nr 52, s. 411-414. 
Sobieski S., Czego mamy obecnie żądać po nauczycielu szkót ludowych, „Szkoła” 1868, t. I, nr 3, s. $152-157$, nr 4, s. 231-237.

Spitzer S., W jaki sposób wpływać może szkoła na wzbudzenie u dzieci poczucia obowiazku, „Szkoła" 1899, nr 21, s. 202-204, nr 22, s. 211-212, nr 24, s. 233-235, nr 27, s. 263-265.

Sprawozdanie Bolesława Adama Baranowskiego odczytane na posiedzeniu Zjazdu Towarzystwa Pedagogicznego dnia 27 sierpnia 1908 r. pt. Czterdziestolecie Towarzystwa Pedagogicznego, w: Księga Jubileuszowa Polskiego Towarzystwa Pedagogicznego 1868-1901, Lwów 1908, s. $1-24$.

St. K., Przeciażenie ale nauczycieli, „Szkoła” 1902, nr 40, s. 297-298.

Stiasny A., Czy i jak może nauczyciel wobec obowiazujących ustaw szkolnych utrzymać łaczność między szkoła a domem? (Rzecz odczytana przez kierownika 2 klasowej szkoty w Woli Wadowskiej na posiedzeniu kótka pedagogicznego w Radomyślu), „Szkoła” 1883, nr 42, s. 332-334.

Synowie nauczycielscy - głos z prowincji, „Szkoła” 1884, nr 2, s. 9-10.

„Szkoła” 1892, nr 1 (numer jubileuszowy).

Szyc St., Jeszcze o przeciażeniu, „Szkoła” 1902, nr 41, s. 332-333.

Święcicki P., Stanowisko nauczyciela wiejskiego, „Szkoła” 1870, nr 36, s. 561-565.

Trzaskowski B., O powinnościach nauczyciela, a w szczególności nauczyciela wiejskiego, „Szkoła” 1895 , nr 4, s. 45-46, nr 5, s. 62-63.

Trzaskowski B., Seminaria nauczycielskie i ustawa obowiazująca Królestwo Galicji i Lodomerii $z$ Wielkiem Księstwem Krakowskiem o seminariach nauczycielskich, „Szkoła” 1869, nr 27, s. $1-8$, nr 28 , s. $17-23$.

Wawro J., O potrzebie pracy nauczyciela poza obrębem izby szkolnej nad oświata młodszego i starszego pokolenia ludu, „Szkoła” 1900, nr 3, s. 18-19, nr 5, s. 26.

Wojnarowski F.K., Dlaczego i jak powinien nauczyciel doświadczać samego siebie, „Szkoła” 1872, nr 48, s. 377-380.

Wojnarski F.K., Jakim powinien być nauczyciel?, „Szkoła” 1874, nr 6, s. 47-48, nr 7, s. 57.

Z nauczycielskiej martyrologii, „Szkoła” 1902, nr 46, s. 348.

Zabierzowski S., O koleżeństwie, „Szkoła” 1889, nr 35, s. 337-339.

Z.M., Powołanie nauczyciela elementarnego, „Szkoła” 1908, nr 51, s. 401-402.

Opracowania

Bobrowska-Nowak W., Problemy pedagogiczne na łamach „Szkoły” w latach siedemdziesiatych ubiegłego stulecia, „Przegląd Historyczno-Oświatowy” 1971, nr 2, s. 261-277.

Głaz E., Zygmunt Sawczyński - pedagog, polityk i działacz oświatowy, w: Galicja i jej dziedzictwo, t. 9, Biografie pedagogiczne. Szkice do portretu galicyjskiej pedagogii, red. C. Majorek, J. Potoczny, Rzeszów 1997, s. 41-58.

Karbowiak A., Polskie czasopisma pedagogiczne, Warszawa 1912.

Lewicki K., Józefczyk Andrzej, w: Polski Stownik Biograficzny, t. XI, Wrocław 1964-1965, s. 303304.

Majorek C., Towarzystwo Pedagogiczne i „Szkoła” wobec projektów reform ksztatcenia nauczycieli ludowych w Galicji z lat 1868-1869, „Rocznik Naukowo-Dydaktyczny WSP w Krakowie” 1972 (z. 43), nr 5, s. 289-300.

Majorek C., Urzędowa koncepcja ideału nauczyciela szkoły ludowej w Galicji doby autonomicznej, „Rocznik Komisji Nauk Pedagogicznych” 1970, T. X, s. 207-222.

Marczewski B., Powołanie, godność i obowiązi stanu nauczycielskiego, „Szkoła” 1891, nr 1, s. 3-4, nr 2, s. $15-16$, nr 3, s. 27-29. 
Meissner A., Bronisław Trzaskowski (1824-1906), w: Studia z dziejów oświaty XVIII-XX wieku, red. M. Chamcówna, Wrocław 1993, s. 67-79.

Meissner A., Spór o duszę polskiego nauczyciela. Społeczeństwo galicyjskie wobec problemów kształcenia nauczycieli, Rzeszów 1999.

Meissner A., Historia i historycy na ziemiach polskich w XX wieku, Lublin 2010.

Meissner A., Stanisław Sobieski, w: Stownik biograficzny polskiej historii wychowania, red. A. Meissner, W. Szulakiewicz, Toruń 2008, s. 758-762.

Potoczny J., Pedagogiczne wyznania Mieczysława Tytusa Baranowskiego, w: Galicja i jej dziedzictwo, t. 9, Biografie pedagogiczne. Szkice do portretu galicyjskiej pedagogii, red. C. Majorek, J. Potoczny, Rzeszów 1997, s. 103-110.

Redakcja, Sobieski Stanisław, w: Polski Stownik Biograficzny, t. XXXIX, Warszawa-Kraków 1999-2000, s. 510-511.

Skorzepianka M., Chmielewski Józef, w: Polski Stownik Biograficzny, t. III, Kraków 1937, s. 325326.

Stopińska-Pająk A., Wkład czasopisma „Szkoła” w rozwój myśli pedagogicznej, w: Galicja i jej dziedzictwo, t. 8, Myśl edukacyjna w Galicji 1772-1918, red. C. Majorek, A. Meissner, Rzeszów 1997, s. 169-179.

Szulakiewicz W., Stanisław Sobieski - życie i poglady na wychowanie narodowe, w: Galicja i jej dziedzictwo, t. 9: Biografie pedagogiczne, red. C. Majorek, J. Potoczny, Rzeszów 1997, s. 59-67.

Szulakiewicz W., Władystaw Seredyński. Studium z dziejów pedagogiki galicyjskiej, Rzeszów 1995.

Świątek A., Problem patriotycznego wychowania ludu na tamach lwowskiej „Szkoły” w czasach autonomii galicyjskiej, w: Czasopiśmiennictwo XIX i początków XX wieku jako źródło do historii edukacji, red. I. Michalska, G. Michalski, Łódź 2010, s. 169-184.

Wałęga A., Dziedzictwo polskiej teorii i praktyki pedagogicznej na kartach „Szkoły”, w: Polskie dziedzictwo pedagogiczne - idee i instytucje, red. J. Falkowska, Pedagogika Toruńska, t. 7, Toruń 2016, s. 59-75.

Wałęga A., Dziedzictwo wielkopolskiej myśli pedagogicznej w przekazie „,Szkoły” (1868-1939), w: Wielkopolska $i$ Wielkopolanie $w$ dziejach polskiej edukacji, red. E. Głowacka-Sobiech, K. Kabacińska-Łuczak, Poznań 2017, s. 475-489.

Wałęga A., Galicyjska „, Szkoła” jako przykład czasopisma pedagogicznego okresu zaborów, „Acta Universitatis Nicolai Copernici - Pedagogika" t. XXIX (2013), s. 9-28.

Wałęga A., Kształcenie i samokształcenie galicyjskich nauczycieli szkót ludowych doby zaborów w przekazie „Szkoły” w: Szkoła polska od XVIII do XXI wieku, red. R. Ślęczka, A. Włoch, J. Wojniak, Kraków 2020, s. 46-65.

Wałęga A., O zadaniach wychowawczych rodziny. Koncepcje wspótpracowników czasopisma „Szkoła”, „Wychowanie w Rodzinie” 2014 (t. X), nr 2 , s. 137-158.

Wałęga A., Rodziny polskie wobec wyzwań i zagrożeń I połowy XX wieku (w świetle „, Szkoły”), „Wychowanie w rodzinie” 2016 (t. XIV), nr 2, s. 209-230. 